NBER WORKING PAPER SERIES

\title{
THE EFFECT OF NICOTINE REPLACEMENT THERAPY ADVERTISING ON YOUTH SMOKING
}

\author{
Henry Saffer \\ Melanie Wakefield \\ Yvonne Terry-McElrath \\ Working Paper 12964 \\ http://www.nber.org/papers/w12964
}

\author{
NATIONAL BUREAU OF ECONOMIC RESEARCH \\ 1050 Massachusetts Avenue \\ Cambridge, MA 02138 \\ March 2007
}

Thanks go to Dhaval Dave and Frank J. Chaloupka for comments on an earlier version of this paper. Thanks also go to Lloyd Johnston and Patrick O'Malley for making the Monitoring the Future data available. Glen Szczypka prepared the raw Nielsen data. The study was supported by funding from the National Cancer Institute State and Community Tobacco Control Initiative. The views expressed herein are those of the author(s) and do not necessarily reflect the views of the National Bureau of Economic Research.

(C) 2007 by Henry Saffer, Melanie Wakefield, and Yvonne Terry-McElrath. All rights reserved. Short sections of text, not to exceed two paragraphs, may be quoted without explicit permission provided that full credit, including $(\subset$ notice, is given to the source. 
The Effect of Nicotine Replacement Therapy Advertising on Youth Smoking

Henry Saffer, Melanie Wakefield, and Yvonne Terry-McElrath

NBER Working Paper No. 12964

March 2007

JEL No. I18

\begin{abstract}
$\underline{\text { ABSTRACT }}$
This paper examines the effect of nicotine replacement therapy (NRT) advertising on youth smoking. NRT advertising could decrease smoking by informing smokers that the product can make quitting easier and thus inducing more smokers to try and quit. However, a moral hazard is created because NRT advertising increases the expectation that cessation is relatively easy. NRT advertising could thus induce youth to smoke, to smoke more and/or to delay quit attempts. Data from Nielsen Media Research (Nielsen) and the Monitoring the Future Surveys (MTF) have been used in the empirical work. The Nielsen data are matched to the MTF data by month, year and market. The availability of lagged advertising data allow for calculation of an advertising stock variable. The Nielsen data also measure exposure to national advertising on a local level which allows for use of national advertising data. An exogenous shock allows for bypassing problems of endogeneity. The results indicate that NRT advertising has no effect on participation but increases smoking by youth who do smoke. The elasticity of smoking with respect to NRT advertising is about .10 and the elasticity of smoking with respect to price is about -1.03 . Since average youth smoking is about 5.77 cigarettes per day, an increase of 10 percent in NRT advertising would increase this average to about 5.82 cigarettes per day. It is also estimated that a ban on NRT advertising would be equivalent to a 10 percent increase in cigarette prices.
\end{abstract}

\section{Henry Saffer}

NBER

365 Fifth Avenue, 5th Floor

New York, NY 10016-4309

hsaffer@gc.cuny.edu

Melanie Wakefield

The Cancer Council Victoria

1 Rathdowne Street

Carlton Victoria 3053 Australia

Melanie.Wakefield@accv.org.au
Yvonne Terry-McElrath

Institute for Social Research, Room 2341

University of Michigan

PO Box 1248, Ann Arbor, MI 48106-1248

yterry@isr.umich.edu 


\section{The Effect of Nicotine Replacement Therapy Advertising on Youth Smoking}

\section{Introduction}

Over the past 11 years there have been major changes in the availability of smoking cessation products and in the regulations affecting the marketing of these products directly to consumers. The main class of products delivers nicotine through a variety of methods, excluding smoking, and are known as nicotine replacement therapy (NRT). ${ }^{1}$ The nicotine delivery systems include inhalers, patches, nasal sprays and gums. The Federal Drug Administration (FDA) approves drugs for prescription sale or for sale over-the-counter (OTC). Prior to 1996, all NRT products were available only by prescription and the advertising of all prescription drugs was subject to onerous disclosure requirements. However, in 1996, nicotine gum and nicotine patches were approved by the FDA for OTC sale. This change made advertising nicotine gum and patches possible. Another important change began in 1995 when the FDA initiated a public comment period on lowering the disclosure requirements for advertising prescription drugs. It was widely accepted that the change would go into effect and in the interim the FDA would not pursue violators of the existing law. Prescription drug makers began to increase their advertising in 1996 in anticipation of the FDA changes. In 1997, the FDA formally reduced the disclosure requirements for direct to consumer advertising of prescription drugs.

Although NRT advertising has increased dramatically since 1996, little is known about its effect on smoking. This paper examines the effect of NRT advertising on

\footnotetext{
${ }^{1}$ A prescription antidepressant called Zyban was approved in 1997 for smoking cessation therapy. To simplify the exposition, NRT advertising refers to both Zyban advertising and NRT advertising.
} 
youth smoking. Over the past 10 years youth smoking has been generally declining. According to the Monitoring the Future (MTF) survey (Johnston et al., 2006) smoking in the past 30 days by $12^{\text {th }}$ graders dropped from 33.5 percent in 1995 to 21.6 percent in 2006 paralleling similar declines in smoking among $8^{\text {th }}$ and $10^{\text {th }}$ graders. These

declined are in part due to public policy efforts to reduce the level of smoking. A special emphasis of these policies has been on youth since few individuals initiate smoking after age 20. The policies to reduce smoking include the restrictions on advertising and promotion of tobacco products contained in the 1998 Master Settlement Agreement, tobacco counteradvertising and large price increase for tobacco. Also, state and local governments have enacted a variety of clean indoor air regulations, and laws restricting youth access to tobacco. States have also increased tobacco taxes which reduces the demand for tobacco especially for youth and have funded a variety of tobacco counteradvertising programs. A number of studies have examined the effects of these policies. However, there have been few studies which examine the effect of NRT advertising on smoking by youth.

\section{Prior studies}

NRT has been shown to be effective in increasing success in smoking cessation in experimental settings. An experimental study by Shiffman et al. (2002) examined smoking cessation rates achieved with NRT in simulated OTC and actual prescription settings. A sample of over 6,000 smokers were given either OTC gum, OTC patch, prescription gum or prescription patch. In the OTC setting no intervention was provided. In the prescription setting, smokers were prescribed gum or patch by their physician. Biochemically verified continuous smoking abstinence (for the past 28 days) was 
assessed at six weeks and at six months. OTC success rates were consistently higher than prescription rates. They conclude that smoking cessation rates achieved with OTC NRT were as good as those under real-world prescribing conditions. Hughes et al. (2003) provide a meta-analysis of eight additional studies of the efficacy of OTC NRT. They also conclude that OTC NRT is effective.

A time series analysis by Hu et al. (2000) examined the effect of NRT sales on cigarette consumption. They use a national time series of quarterly per capita cigarette consumption, sales of nicotine gums and patches between 1976 and 1998 and estimate an autoregressive moving average intervention model. The model indicates that a $0.076 \%$ reduction in cigarette consumption is associated with the availability of nicotine patches after 1992. However, the 1996 shift variable, which was included to account for OTC availability, is not significant. They argue that there may not have been enough post 1996 data to have a significant effect.

Cummings and Hyland (2005) present a less optimistic picture of OTC NRT. They study the effect of NRT on altering population trends in smoking behavior. They find that fewer than one in five smokers making a quit attempt do so with the benefit of NRT. Because not enough smokers are using NRT, they conclude that NRT has not had a measurable impact on influencing population trends in smoking behavior. The reasons smokers provide for not wanting to use NRT is the cost of NRT and concerns that it will not work. Cummings and Hyland (2005) argue that the OTC versions of NRT may have too little nicotine to be effective and that is why Hu et al. found no post 1996 effect and why people may think that OTC NRT is not effective. However, they also present data from an NRT give-away program in New York City. Over 400,000 people were called to get free nicotine patches and a follow-up survey six months later found 
that 33 percent of the patch recipients reported that they were not smoking. Cummings and Hyland's findings suggest that NRT sales may have only a limited effect on smoking behavior. Since advertising, in general, has only a limited effect on sales it is not certain that NRT advertising will have sufficient power to influence smoking. lizuka and Jin (2005) examine the effects of NRT advertising on smoking participation, use and quit attempts. They merge NRT advertising data with data from the Behavioral Risk Factor Surveillance Survey (BRFSS). The NRT data is the prior year's cumulative expenditure which is linked to the current year smoking data for 73 markets over five years including 1997 to 2001 . The use of annual advertising data is not desirable because of temporal aggregation bias (Leone, 1995). In addition, they use only spot TV advertising, spot radio and outdoor as the measure of NRT advertising. This is only approximately three percent of total advertising expenditures. ${ }^{2}$ In the 12 regressions presented by lizuka and Jin, NRT advertising is negative and significant in only two. They conclude that there is no effect of NRT advertising on smoking. However, they only find that price is negative and significant in three equations which suggests that there may be specification problems in these regressions.

Both Cummings and Hyland (2005) and lizuka and Jin (2005) note the moral hazard problem associated with NRT advertising. The moral hazard is created since NRT advertising can increase the expectation that cessation is relatively easy with the use of NRT. According to Fong (2001) many youth underestimate the addictive power of smoking. Among high school smokers, only five percent expect to be smoking five

\footnotetext{
${ }^{2}$ According to Avery et al. (2006) in 1999, NRT advertising on TV was about $\$ 170$ million and in magazines was about $\$ 20$ million. lizuka and Jin (2005) report that local radio, local TV and outdoor NRT advertising in 1999 was about $\$ 5.3$ million.
} 
years after graduation, however, follow-up data shows that 75 percent will still be smoking. The moral hazard problem occurs if NRT advertising, which suggests that quitting can be easy, results in more youth choosing to smoke, to smoke more and to delay quit attempts.

\section{Empirical Model and Data}

To develop the empirical model assume that the choice to smoke by adolescents can be viewed as a multi-period utility maximization problem subject to a cost constraint. Smoking provides utility but has immediate pecuniary, social and health costs. Health costs also increase over time. The importance of these future health costs depend on the youth's rate of time preference and assessment of the addictive power of cigarettes. The probability of smoking increases with utility and with discounting of the future and decreases as the expected difficulty of future cessation increases. Knowledge about NRT reduces the expected difficulty of future cessation. This could increase current smoking. Knowledge about NRT would lead to increased use of NRT and decrease future smoking. Thus knowledge about NRT has no a priori expectation in general. A demand for cigarettes, $C_{i j}$, can be derived from this theoretical utility maximization model. Knowledge about NRT is measured by NRT advertising. Let $\mathrm{i}$ stand for the individual, $\mathrm{j}$ stand for the local area and $\mathrm{t}$ stand for time. This demand function is:

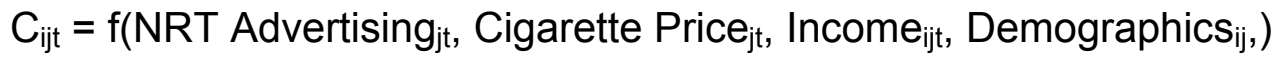

The data set employed to estimate this equation was created by merging data obtained through the Youth Smoking and the Media study (supported by the National Cancer Institute) from Nielsen Media Research (Nielsen), data from ImpacTeen 
(supported by the Robert Wood Johnson Foundation), and data from the Monitoring the Future (MTF) Surveys (supported by the National Institute on Drug Abuse). Nielsen provided the NRT advertising data and ImpacTeen provided the data on tobacco prices. The MTF data include variables measuring smoking, demographics and certain youth characteristics. The data are a pool of cross sections of $8^{\text {th }}$ graders, $10^{\text {th }}$ graders and $12^{\text {th }}$ graders from 1994 to 2003 . This pool is a nationally representative sample of over 200,000 high school students. Pooling these years increases the variance in advertising and tobacco policy variables.

The advertising data measures potential audience exposure to all NRT advertising on network and cable television for the largest 50 media markets in the US. ${ }^{3}$ These 50 markets accounted for about $60 \%$ of American viewing households (Nielsen Media Research, 2002). Data for each commercial occurrence were aggregated by market and month. Nielsen data are based on individual ratings of television programs, obtained by monitoring household audiences across media markets. Ratings provide an estimate of the percentage of households with televisions watching a program or advertisement in a media market over a specified time interval. Advertising is measured by Gross Ratings Points (GRP), which is an estimate of the reach times the frequency of advertising. Reach is defined as the percent of the potential market which has viewed an ad and frequency is the number of times an average viewer has seen the ad. For example, if a market has $80 \mathrm{GRPs}$ for a given month it can be interpreted to mean that $80 \%$ of the market has seen one ad or that 40 percent of the market has seen two ads, etc. GRPs represent a probability of individual exposure to an advertisement. ${ }^{4}$

\footnotetext{
${ }^{3}$ Only 50 markets were available for the entire sample period.

${ }^{4}$ Teenage Targeted Rating Points (TRP) were also available but produced the same results in the regressions as GRPs. GPRs were used in the reported results since teens can also view ads that are not targeted to them.
} 
The GRPs for all NRT advertising, by market and by month, are aggregated to create the advertising data.

As a measure of advertising, GRPs have an advantage over advertising expenditures. The advantage of GRPs is that they measure the impact of national TV advertising on the local level. The local level is a designated market area (DMA) which is defined by Nielsen and is similar to the concept of a metropolitan statistical area used by the US government. National TV expenditures have no reported local variation. Local variation in expenditures are limited to spot TV advertising, spot radio and outdoor. National TV NRT advertising expenditures represent about 80 percent of total NRT advertising while spot media represent about five percent of total NRT advertising expenditures. In this paper, the use of GRPs to measure NRT advertising improves on expenditures since GRPs measure the impact of 80 percent of total advertising on the DMA level.

The ImpacTeen data on cigarette prices is the real price (using the 1982-1984 Consumer Price Index) of a pack of cigarettes which is the state average for the first six months of each year excluding generics.

Since the MTF data include many youth who do not smoke, the smoking equation is estimated using a two-part specification. The demand for cigarettes is divided into a decision to smoke, which is defined as participation, and a decision on how much to smoke, given participation, which is defined as use. Participation may be more accurate since it is easier for a respondent to recall whether or not they smoked rather than how much they smoked. Participation is measured with an indicator variable and use, given participation, is measured by a continuous variable. The participation equation is estimated with probit and the use given participation is estimated with OLS. 
The use variable is converted to its natural log. Both participation and use equations are non-linear specifications which allow for a diminishing marginal product of NRT advertising.

The MTF data allows for definition of a set of demographic and other independent variables. Several dichotomous independent variables were constructed. These variables are defined as equal to one if the individual is a member of the group defined by the variable name. These variables are male, white, African American, Hispanic, $10^{\text {th }}$ grade and $12^{\text {th }}$ grade. An additional dichotomous variable, lives with both parents, is equal to one if the condition is true. Additional continuous variables from the MTF are student's real earned income (using 1982-1984 Consumer Price Index) and years of parent education, averaged for both parents, if available. The regressions also include dichotomous year variables, month variables and some regressions include either state, or DMA dichotomous variables.

The advertising data and ImpacTeen data were merged with individual level data from the MTF. The individual data is coded by month, year and school zip code in the MTF. Similarly the Nielsen advertising data is available by month, year and DMA, which can be matched to zip codes. In addition, advertising data for a number of prior months is also available by month, year and DMA. The individual data and advertising data can thus be matched by month, year and DMA along with several months of prior advertising data.

Measuring advertising by month is important since it minimizes temporal aggregation bias. This bias results from the length of the time interval used to measure the advertising data. Aggregation over a long interval will obscure important variance in the advertising variable. A review paper by Leone (1995) finds the effects of advertising 
do not linger more than six to nine months which makes aggregation over intervals of more than nine months likely to create bias. Advertising data used in this paper is measured in monthly intervals which minimizes this bias.

A related issue in estimating the effects of advertising is accounting for the lagged effects of advertising. These lagged effects result in a stock of advertising. The advertising variable used in this study is defined as a weighted sum of current and lagged advertising data. The lag period is one month. The weights used depend on the carryover effect. The carryover effect is the ratio of the effect of last month's advertising on consumption to the effect of this month's advertising on consumption. The carryover effect is assumed to be constant and is referred to as $\lambda$. This assumption creates an exponential decay process. The weights are thus $\lambda^{t}$ where $t$ is the number of months since the advertisement was aired. Pollay et al. (1996) conclude that for tobacco a carryover effect of .3 is a reasonable value. ${ }^{5}$ The advertising variable used in this study was created by summing the current month and three prior months advertising, weighted by $\cdot 3^{\mathrm{t}}$. That is, the advertising stock variable is equal to the current month advertising and the weighted GRPs for the past three months. The current month is the month of the MTF survey data. The mean values for all of the variables used in the regressions are presented in table 1.

An important issue in advertising research is endogeneity between consumption and advertising. NRT advertisers might spend more in DMA's with more smokers. The number of smokers of all ages is positively correlated with the number of youth smokers. Therefore, it is possible that youth smoking is a causal factor on NRT

\footnotetext{
${ }^{5}$ Other decay rates were tested and produced very similar regression results. With a decay rate of .3 , after three months the weight is only .027 which make a negligible contribution to the advertising stock.
} 
advertising. However, there was an exogenous shock in NRT advertising in 1996. This shock, described in the introduction, was the result of the shift to OTC and the lowering of the disclosure requirements for DTC advertising of all prescription drugs. The monthly data on NRT advertising for all 50 DMAs are shown in figure 1. As seen in figure 1, there is a dramatic change in NRT advertising beginning in March 1996. Since this change is exogenous to smoking, endogeneity is not a problem in the immediate pre-shock and post-shock periods. However, the greater the elapse of time before or after the shock increases the probability of endogeneity. There was no NRT advertising pre-shock, but endogeneity can still occur in the post-shock period. To limit advertising variance primarily to the 1996 exogenous shock, models using only 1994 through 1997 data were also estimated.

Figure 1 also shows a seasonal pattern of increased NRT advertising around January of each year. For this reason, month level dichotomous variables are also included in the regressions. The MTF surveys are all done from February to June so month variables for March through June were included.

It is possible that within geographical groups there exists unobservable factors which are correlated across all individuals. This creates a potential correlation in the error terms for individuals in the same geographical group. To correct this clustered standard errors are used. The cluster is defined at the DMA level.

The regression models also control for a series of alternative fixed effects. All models include time fixed effects that capture unobserved national trends and timevarying factors common to states or DMAs. Cross sectional fixed effects models are also important since the correlation between NRT advertising and smoking may simply 
reflect the contemporaneous effects of some other unobserved factors such as local sentiment towards smoking.

4. Results

Table 2 presents the estimation results for both smoking participation and use. The participation regressions are estimated using probit and the use regressions are estimated with OLS using the natural $\log$ of use. Equations 1, 2 and 3, respectively, include no fixed effects, state fixed effects variables and DMA fixed effects variables. All equations include year fixed effects variables. The coefficients of the fixed effects variables are not presented in table 2 in order to simplify the table. All of these equations use DMA level clustered standard errors to compute the significance tests.

The alternative fixed effects models show how the estimates for NRT advertising and cigarette price are affected by the inclusion of controls for geographic unobservables. The NRT advertising variable and the price variable may have a component which varies systematically with location making these variables, in part, proxies for local level unobservables. If this is the case, the exclusion of the fixed effects variables would bias the coefficients of the NRT advertising and price variables. However, the inclusion of locational fixed effects variables could create colinearity with the NRT advertising variable or the price variable. This colinearity can bias the standard errors. When a variable is significant in both regressions with and without locational fixed effects it is less likely to be the result of colinearity between the NRT advertising and the locational fixed effects variables or between price and the locational fixed effects variables. If this is the case then the coefficients from the fixed effects models are preferred since locational effects are controlled. 
The inclusion of locational fixed effects variables is equivalent to aggregation of the data to the level of the fixed effects variables. The DMA locational fixed effects variables aggregate the data to the DMA level. The results for NRT advertising from the models with DMA locational fixed effects variables are preferred since NRT is measured at the DMA level. However, the cigarette price variable will have the same value for several values of the dependent variable. This will create a lower t-value for the price coefficient in the DMA regression than price would have in the state level fixed effects regression. Thus the results for price from models with state level fixed effects are preferred to the results from the DMA level fixed effects models.

In table 2 the results for NRT advertising differ between the participation regressions and the use regressions. The NRT advertising variable is insignificant in each participation regression. For use, NRT advertising is significant in the model with no locational fixed effects and the state fixed effects model. NRT advertising in the DMA level fixed effects model is positive but not significant. The magnitude of the coefficients declines in the fixed effects model suggesting that the NRT advertising variable is picking up some locational variation. These results provide evidence that NRT advertising does not affect smoking participation by youth. However, there is evidence that NRT advertising does increase the amount of smoking by youth who already smoke.

The cigarette price variable is negative and generally significant. The state cigarette price is negative in all regressions and significant in five of six regressions in table 2. The insignificant coefficient is in the DMA level fixed effects regression which is unimportant since the price varies at the state level. The evidence suggests a negative effect of price on both participation and use. 
Endogeneity was limited by an exogenous shock in NRT advertising. However, in the post-shock period endogeneity can again become a concern. Once NRT advertising was allowed, advertisers may target advertising to smokers which would create endogeneity in the post-shock period. The further away from the shock, the greater the concern over endogeneity. The least amount of endogeneity occurs when using data very close to the shock since the variation in advertising is primarily related to the shock. In order to examine the results presented in table 2 for endogeneity in the post-shock period, an additional set of models have been estimated for a limited time period. This time period includes the two years before and two years after the exogenous shock in 1996. That is, the data are limited to 1994 through 1997. Any endogeneity between NRT advertising and smoking would be minimized in this relatively small period around the shock. There are five months of data in each year and 50 DMAs resulting in approximately 1000 NRT advertising data points in this experiment. Results from the limited time period models are presented in table 3.

The results in table 3 again show that there is no effect of NRT advertising on participation but NRT advertising is again found to have positive and significant effect on use. The magnitude of the NRT advertising coefficients increase in the limited time period models while the coefficients of the individual characteristics do not change significantly between the sample periods. This is what would occur if NRT advertising were correlated with the error term but the other independent variables were not. The implication is that there is endogeneity between NRT advertising and smoking in the post-shock period. The NRT advertising coefficients from the limited period presented 
in table 3 are thus preferred to those of table $2 .{ }^{6}$

The demographic variables in both table 2 and 3 follow patterns that are familiar from prior research. These individual level variables are generally not affected by alternative fixed effects specifications. This shows no location aspect to the individual level variables. Student income has a positive effect on both participation and use. Males have lower participation but a higher level of use than females. African Americans and Hispanics have both lower participation and use relative to the omitted group. However, whites have higher participation and use relative to the omitted group. Parental education has a negative effect on use. Finally, participation and use increases as the student advances to higher grades. The month variables are mixed, with some significant and some insignificant coefficients.

Table 4 presents the NRT advertising coefficients from a series of regressions which were limited to data for specific demographic groups. These results are based on data from 1994 to 1997 . The table presents only the NRT advertising coefficients since other variables where substantially the same as table 3 . The demographic group is listed in the first column. Again, the evidence of an effect is stronger when at least two specifications have significant coefficients. The results suggest that NRT advertising has a greater impact on $12^{\text {th }}$ graders, whites and the "other" race category. Younger students, African Americans and Hispanics appear to be unaffected by NRT advertising. Use by males and females are increased equally by NRT advertising.

\section{Conclusions}

\footnotetext{
${ }^{6}$ It is also possible that the difference in NRT coefficients may be due to some phenomena other than endogeneity.
} 
The purpose of this project was to determine the effect that NRT advertising has on youth smoking. NRT advertising could decrease smoking by informing smokers that the product can make quitting easier and thus inducing more smokers to try and quit. However, a moral hazard is created because NRT advertising increases the expectation that cessation is relatively easy. NRT advertising, therefore, could induce individuals to initiate smoking, to smoke more and to delay quit attempts.

There is no theoretical reason that NRT advertising would have a different effect on participation and use. Yet the results show that NRT advertising has no effect on participation but increases use. Participation is affected by both initiation and cessation. Possibly, NRT advertising increases initiation but also increases cessation. This could result in no overall effect on participation. Alternatively, NRT advertising may simply have no effect on participation.

Both NRT advertising elasticities and price elasticities can be computed. Using the results for the DMA fixed effects model of use in table 3 an elasticity of smoking with respect to NRT advertising can be computed. This elasticity is computed to be .10 , which means that an increase of 10 percent in NRT advertising would increase smoking by about 1.0 percent. $^{7}$ Since average youth smoking is about 5.77 cigarettes per day, an increase of 10 percent in NRT advertising would increase this average to about 5.82 cigarettes per day.

The NRT advertising elasticity can also be used to estimate the effect on youth smoking of banning all NRT advertising. The relationship between NRT advertising and youth smoking is likely to be non-linear with the elasticity decreasing as NRT advertising

\footnotetext{
${ }^{7}$ The NRT advertising variable is a weighted sum of the current and past three months of advertising. It can easily be shown that if advertising in all four months changes by 10 percent, then the weighted sum also changes by 10 percent.
} 
increase. The estimated elasticity thus underestimates the effect of eliminating NRT advertising entirely. A 100 percent decrease in NRT advertising is estimated to reduce youth smoking by at least 10 percent. This would reduce youth smoking from 5.77 cigarettes per day to about 5.27 , or less, cigarettes per day.

As a comparison the price elasticity is also computed from the four relevant price coefficients in tables 2 and 3 . The four price coefficients for participation average to about -.0014 which results in an elasticity of about -.68 . The four price coefficients for use from average to -.0035 which results in an elasticity of about -.45 . The overall price elasticity is -1.03 , while somewhat high, is the price elasticity for youth rather than adults. The elasticity indicates that a 10 percent increase in price would reduce youth smoking by about 10 percent. This is the same as a complete elimination of NRT advertising.

Further research on the effects of NRT advertising on older smokers is important before any definitive conclusions about NRT advertising are made. NRT advertising may be important in helping older smokers to quit. If this is the case, to limit the damage to younger smokers, NRT advertising could be targeted at older smokers by limiting the type of programming that show NRT ads and by the content of the ads themselves. 


\section{References}

Avery, R. Kenkel, D. Lillard, D. Mathios, A. "Private Profits and Public Health: Does Advertising of Smoking Cessation Products Encourage Smokers to Quit?", Department of Policy Analysis \& Management, Cornell University, 2006.

Cummings, K. and Hyland, A. "Impact of Nicotine Replacement Therapy on Smoking Behavior", Annual Review of Public Health, Vol. 26, 2005, pp. 583-599.

Emery, S. et al. "An examination of the relationship between televised anti-tobacco advertising and youth smoking beliefs and behavior", Archives of Pediatric Medicine, 2005.

Fong, G. " A Review of the Research on Tobacco Warning Labels, With Particular Emphasis on the New Canadian Warning Labels", manuscript, University of Waterloo, 2001.

Hu, T. Sung, H. Keeler, T. Marciniak, M. "Cigarette Consumption and Sales of Nicotine Replacement Products”, Tobacco Control, Suppl. II, Summer, 2000.

Hughes, J, Shiffman, S., Callas P., and Zhang, J., "A meta-analysis of the efficacy of over-the-counter nicotine replacement”, Tobacco Control, vol. 12, pp 21-27, 2003.

lizuka, T. and Jin, G. Z. "Drug Advertising and Health Habits.” National Bureau of Economic Research Working Paper no. 11770, 2005.

Johnston, L. D., O'Malley, P. M., Bachman, J. G., \& Schulenberg, J. E. (2006). Monitoring the Future national survey results on drug use, 1975-2005. Volume I: Secondary school students (NIH Publication No. 06-5883). Bethesda, MD: National Institute on Drug Abuse.

Leone, R., "Generalizing What is Known About Temporal Aggregation and Advertising Carryover", Marketing Science, Vol. 14 Issue 3, pp. 141-151, 1995.

Nielsen Media Research, Inc. Top 50 TV Markets Ranked by Households, Nielsen Station Index, 2002.

Pollay, R., Siddarth, S., Siegel, M,, Haddix, A., Merritt, R., Giovino, G., Eriksen, M., "The Last Straw? Cigarette Advertising and Realized Market Shares Among Youths and Adults, 1979-1993", Journal of Marketing, Vol. 60, Issue 2, April 1996.

Shiffman, S. et al. "Real-world efficacy of prescription and over-the-counter nicotine replacement therapy”, Addiction, 97, pp. 550-516, 2002.

Tworek, C. et al. "Exploring the Relationship Between Cigarette Smoking Among Adolescents and Adults in the United States", ImpacTeen Research Paper Series, No. 26, http://www.impacteen.org/generalarea PDFs/youthadult tworek042303.pdf, April 2003. 
Figure 1

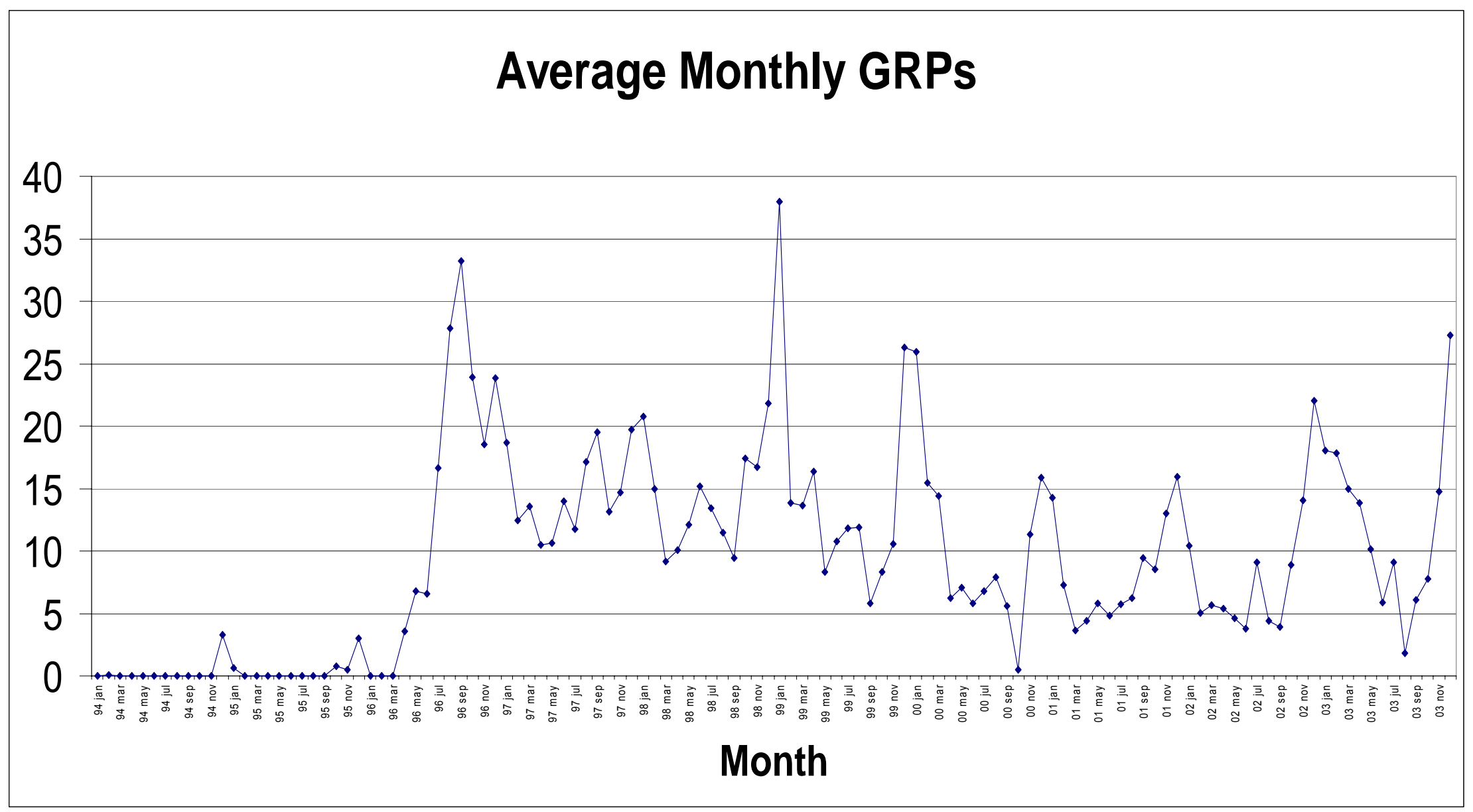




\section{Table 1}

Means

\begin{tabular}{|c|c|c|c|}
\hline Variable & Definition & $1994-2003$ & 1994-1997 \\
\hline $\begin{array}{l}\text { Smoking } \\
\text { Participation }\end{array}$ & $\begin{array}{l}\text { Dichotomous variable for whether respondent smoked any } \\
\text { cigarettes during the past } 30 \text { days }\end{array}$ & 0.2244 & 0.2632 \\
\hline $\begin{array}{l}\text { Smoking } \\
\text { Consumption }\end{array}$ & $\begin{array}{l}\text { Number of cigarettes smoked during the past } 30 \text { days among } \\
\text { smokers: }<1 / \text { day }(0.5) ; 1-5 / \text { day }(3) \text {; about } 1 / 2 \text { pack/day }(10) ; \\
\text { about } 1 \text { pack/day }(20) ; \text { about } 11 \frac{1}{2} \text { packs/day }(30) ; 2+\text { packs/day } \\
(40)\end{array}$ & 5.5545 & 5.7715 \\
\hline $\begin{array}{l}\text { Ln Smoking } \\
\text { Consumption }\end{array}$ & Natural log of cigarette consumption scale above & 0.7574 & 0.7919 \\
\hline NRT Advertising & $\begin{array}{l}\text { NRT advertising stock variable equal to the current month } \\
\text { advertising and the decay weighted GRPs for the past three } \\
\text { months }\end{array}$ & 12.4491 & 5.9221 \\
\hline $\begin{array}{l}\text { State Cigarette } \\
\text { Price }\end{array}$ & $\begin{array}{l}\text { Real price (using the 1982-1984 Consumer Price Index) of a } \\
\text { pack of cigarettes which is the state average for the first six } \\
\text { months of each year excluding generics }\end{array}$ & 167.6560 & 128.9797 \\
\hline Income & $\begin{array}{l}\text { Average weekly income from all sources, in dollars, adjusted } \\
\text { by the } 1982-1984 \text { Consumer Price Index }\end{array}$ & 30.0740 & 30.8484 \\
\hline Male & Dichotomous variable for whether the respondent is male & 0.4776 & 0.4864 \\
\hline African American & $\begin{array}{l}\text { Dichotomous variable for whether the respondent is African } \\
\text { American }\end{array}$ & 0.1297 & 0.1150 \\
\hline Hispanic & Dichotomous variable for whether the respondent is Hispanic & 0.1158 & 0.1131 \\
\hline White & Dichotomous variable for whether the respondent is White & 0.6372 & 0.6557 \\
\hline Other Race & $\begin{array}{l}\text { Dichotomous variable for whether the respondent is any race } \\
\text { other than African American, Hispanic, or White }\end{array}$ & 0.1173 & 0.1162 \\
\hline $8^{\text {th }}$ Grade & $\begin{array}{l}\text { Dichotomous variable for whether the respondent is in } 8^{\text {th }} \\
\text { grade }\end{array}$ & 0.3580 & 0.3337 \\
\hline $10^{\text {th }}$ Grade & $\begin{array}{l}\text { Dichotomous variable for whether the respondent is in } 10^{\text {th }} \\
\text { grade }\end{array}$ & 0.3353 & 0.3526 \\
\hline $12^{\text {th }}$ Grade & $\begin{array}{l}\text { Dichotomous variable for whether the respondent is in } 12^{\text {th }} \\
\text { grade }\end{array}$ & 0.3067 & 0.3137 \\
\hline $\begin{array}{l}\text { Lives with Both } \\
\text { Parents }\end{array}$ & $\begin{array}{l}\text { Dichotomous variable for whether the respondent reports that } \\
\text { both parents live in the home }\end{array}$ & 0.7472 & 0.7524 \\
\hline $\begin{array}{l}\text { Mean Parental } \\
\text { Education }\end{array}$ & $\begin{array}{l}\text { Years of parent education, averaged for both parents, if } \\
\text { available }\end{array}$ & 14.0619 & 14.0255 \\
\hline February & $\begin{array}{l}\text { Dichotomous variable for whether the respondent's school was } \\
\text { surveyed in February }\end{array}$ & 0.0368 & 0.0262 \\
\hline March & $\begin{array}{l}\text { Dichotomous variable for whether the respondent's school was } \\
\text { surveyed in March }\end{array}$ & 0.3041 & 0.2537 \\
\hline April & $\begin{array}{l}\text { Dichotomous variable for whether the respondent's school was } \\
\text { surveyed in April }\end{array}$ & 0.4339 & 0.4651 \\
\hline May & $\begin{array}{l}\text { Dichotomous variable for whether the respondent's school was } \\
\text { surveyed in May }\end{array}$ & 0.2129 & 0.2492 \\
\hline June & $\begin{array}{l}\text { Dichotomous variable for whether the respondent's school was } \\
\text { surveyed in June }\end{array}$ & 0.0123 & 0.0058 \\
\hline \multicolumn{2}{|c|}{$\begin{array}{l}\text { Number of Observations for Smoking Participation Models (and for all variables other } \\
\text { than smoking consumption) }\end{array}$} & 247,063 & 93,778 \\
\hline \multicolumn{2}{|c|}{ Number of Observations for Smoking Consumption Models } & 55,435 & 24,686 \\
\hline
\end{tabular}


Table 2

Smoking Participation and Consumption, Total Sample (1994-2003) ${ }^{1}$

\begin{tabular}{|c|c|c|c|c|c|c|}
\hline \multirow[t]{3}{*}{ Variables } & \multicolumn{3}{|c|}{ Participation } & \multicolumn{3}{|c|}{ (LN) Use } \\
\hline & 1 & 2 & 3 & 1 & 2 & 3 \\
\hline & Probit & $\begin{array}{l}\text { Probit } \\
\text { State FE }\end{array}$ & $\begin{array}{l}\text { Probit } \\
\text { DMA FE }\end{array}$ & OLS & $\begin{array}{c}\text { OLS } \\
\text { State FE }\end{array}$ & $\begin{array}{c}\text { OLS } \\
\text { DMA FE }\end{array}$ \\
\hline $\begin{array}{l}\text { NRT } \\
\text { advertising }\end{array}$ & $\begin{array}{r}0.0012 \\
(1.58)\end{array}$ & $\begin{array}{r}-0.0003 \\
(-0.50)\end{array}$ & $\begin{array}{r}-0.0007 \\
(-1.18)\end{array}$ & $\begin{array}{r}0.0113 \\
(2.68)\end{array}$ & $\begin{array}{r}0.0054 \\
(1.88)\end{array}$ & $\begin{array}{r}0.0039 \\
(1.43)\end{array}$ \\
\hline $\begin{array}{l}\text { State price } \\
\text { cigarettes }\end{array}$ & $\begin{array}{r}-0.0006 \\
(-3.78)\end{array}$ & $\begin{array}{r}-0.0006 \\
(-2.94)\end{array}$ & $\begin{array}{r}-0.0003 \\
(-3.02)\end{array}$ & $\begin{array}{r}-0.0023 \\
(-2.90)\end{array}$ & $\begin{array}{r}-0.0029 \\
(-1.96)\end{array}$ & $\begin{array}{r}-0.0007 \\
(-0.91)\end{array}$ \\
\hline $\begin{array}{l}\text { Student } \\
\text { income }\end{array}$ & $\begin{array}{l}0.0018 \\
(39.76)\end{array}$ & $\begin{array}{l}0.0018 \\
(45.52)\end{array}$ & $\begin{array}{l}0.0018 \\
(44.25)\end{array}$ & $\begin{array}{l}0.0066 \\
(21.83)\end{array}$ & $\begin{array}{l}0.0065 \\
(21.03)\end{array}$ & $\begin{array}{l}0.0064 \\
(20.56)\end{array}$ \\
\hline Male & $\begin{array}{r}-0.0166 \\
(-3.69)\end{array}$ & $\begin{array}{r}-0.0168 \\
(-3.72)\end{array}$ & $\begin{array}{r}-0.0172 \\
(-3.82)\end{array}$ & $\begin{array}{r}0.0745 \\
(5.71)\end{array}$ & $\begin{array}{r}0.0768 \\
(5.42)\end{array}$ & $\begin{array}{r}0.0754 \\
(5.48)\end{array}$ \\
\hline $\begin{array}{l}\text { African } \\
\text { American }\end{array}$ & $\begin{array}{l}-0.1283 \\
(-13.97) \\
\end{array}$ & $\begin{array}{l}-0.1341 \\
(-17.55) \\
\end{array}$ & $\begin{array}{l}-0.1350 \\
(-17.44) \\
\end{array}$ & $\begin{array}{l}-0.5885 \\
(-13.69) \\
\end{array}$ & $\begin{array}{l}-0.6190 \\
(-18.00) \\
\end{array}$ & $\begin{array}{l}-0.6311 \\
(-17.82) \\
\end{array}$ \\
\hline Hispanic & $\begin{array}{r}-0.0145 \\
(-2.08)\end{array}$ & $\begin{array}{r}-0.0076 \\
(-1.45)\end{array}$ & $\begin{array}{r}-0.0043 \\
(-0.83)\end{array}$ & $\begin{array}{l}-0.4802 \\
(-14.42)\end{array}$ & $\begin{array}{l}-0.4343 \\
(-15.96)\end{array}$ & $\begin{array}{l}-0.4095 \\
(-14.00)\end{array}$ \\
\hline White & $\begin{array}{l}0.0703 \\
(10.23)\end{array}$ & $\begin{array}{l}0.0617 \\
(11.58)\end{array}$ & $\begin{array}{l}0.0583 \\
(10.57)\end{array}$ & $\begin{array}{r}0.1081 \\
(4.26)\end{array}$ & $\begin{array}{r}0.0662 \\
(2.95)\end{array}$ & $\begin{array}{r}0.0492 \\
(2.35)\end{array}$ \\
\hline Grad & $\begin{array}{l}0.0727 \\
(11.55)\end{array}$ & $\begin{array}{l}0.0668 \\
(10.55)\end{array}$ & $\begin{array}{l}0.0659 \\
(10.51)\end{array}$ & $\begin{array}{l}0.2481 \\
(11.03)\end{array}$ & $\begin{array}{l}0.2390 \\
(11.65)\end{array}$ & $\begin{array}{l}0.2291 \\
(11.42)\end{array}$ \\
\hline Grad & $\begin{array}{l}0.0975 \\
(14.70)\end{array}$ & $\begin{array}{l}0.0987 \\
(14.67)\end{array}$ & $\begin{array}{l}0.0986 \\
(14.94)\end{array}$ & $\begin{array}{l}0.3737 \\
(14.71)\end{array}$ & $\begin{array}{l}0.3862 \\
(15.52)\end{array}$ & $\begin{array}{l}0.3845 \\
(15.29)\end{array}$ \\
\hline $\begin{array}{l}\text { Lives with } \\
\text { both parents }\end{array}$ & $\begin{array}{l}-0.0592 \\
(-18.59)\end{array}$ & $\begin{array}{l}-0.0600 \\
(-19.06)\end{array}$ & $\begin{array}{l}-0.0601 \\
(-18.94)\end{array}$ & $\begin{array}{l}-0.2855 \\
(-19.32)\end{array}$ & $\begin{array}{l}-0.2879 \\
(-19.49)\end{array}$ & $\begin{array}{l}-0.2876 \\
(-19.47)\end{array}$ \\
\hline $\begin{array}{l}\text { Parental } \\
\text { education }\end{array}$ & $\begin{array}{r}-0.0094 \\
(-8.62) \\
\end{array}$ & $\begin{array}{r}-0.0090 \\
(-8.31) \\
\end{array}$ & $\begin{array}{r}-0.0089 \\
(-8.12) \\
\end{array}$ & $\begin{array}{l}-0.0764 \\
(-15.21)\end{array}$ & $\begin{array}{l}-0.0735 \\
(-13.80)\end{array}$ & $\begin{array}{l}-0.0729 \\
(-13.41)\end{array}$ \\
\hline March & $\begin{array}{r}0.0095 \\
(1.01) \\
\end{array}$ & $\begin{array}{r}0.0038 \\
(0.43)\end{array}$ & $\begin{array}{r}0.0013 \\
(0.15)\end{array}$ & $\begin{array}{r}0.1082 \\
(2.67)\end{array}$ & $\begin{array}{r}0.0649 \\
(1.63)\end{array}$ & $\begin{array}{r}0.0651 \\
(1.67)\end{array}$ \\
\hline April & $\begin{array}{r}0.0130 \\
(1.39) \\
\end{array}$ & $\begin{array}{r}0.0089 \\
(1.08)\end{array}$ & $\begin{array}{r}0.0050 \\
(0.60)\end{array}$ & $\begin{array}{r}0.1347 \\
(3.22)\end{array}$ & $\begin{array}{r}0.0783 \\
(1.95)\end{array}$ & $\begin{array}{r}0.0709 \\
(1.78)\end{array}$ \\
\hline May & $\begin{array}{r}0.0027 \\
(0.27)\end{array}$ & $\begin{array}{r}-0.0007 \\
(-0.08)\end{array}$ & $\begin{array}{r}-0.0039 \\
(-0.45)\end{array}$ & $\begin{array}{r}0.0903 \\
(2.39)\end{array}$ & $\begin{array}{r}0.0500 \\
(1.31)\end{array}$ & $\begin{array}{r}0.0527 \\
(1.39)\end{array}$ \\
\hline June & $\begin{array}{r}-0.0198 \\
(-1.36)\end{array}$ & $\begin{array}{r}-0.0105 \\
(-0.82)\end{array}$ & $\begin{array}{r}-0.0073 \\
(-0.59) \\
\end{array}$ & $\begin{array}{r}-0.0669 \\
(-0.65)\end{array}$ & $\begin{array}{r}-0.0353 \\
(-0.52)\end{array}$ & $\begin{array}{r}-0.0133 \\
(-0.19)\end{array}$ \\
\hline Constant & & & 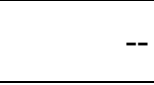 & $\begin{array}{r}1.6488 \\
(12.46) \\
\end{array}$ & $\begin{array}{r}1.5530 \\
(5.74) \\
\end{array}$ & $\begin{array}{r}1.4846 \\
(9.94) \\
\end{array}$ \\
\hline R-Square & 0.0764 & 0.0804 & 0.0814 & 0.0923 & 0.0990 & 0.1011 \\
\hline Observations & 247,063 & 247,063 & 247,063 & 55,435 & 55,435 & 55,435 \\
\hline
\end{tabular}

${ }^{1}$ Not shown are dichotomous year variables in all models; also not shown are dichotomous state and DMA variables in the second and third models, respectively. Probit results are marginal effects; $z-$ and t-values reported in parentheses. The standard errors are clustered at the DMA level.

${ }^{2}$ Probit models report pseudo R-Square; OLS models report adjusted R-Square. 
Table 3

Smoking Participation and Consumption, limited to $1994-1997^{1}$

\begin{tabular}{|c|c|c|c|c|c|c|}
\hline \multirow[t]{3}{*}{ Variables } & \multicolumn{3}{|c|}{ Participation } & \multicolumn{3}{|c|}{ (LN) Use } \\
\hline & 1 & 2 & 3 & 1 & 2 & 3 \\
\hline & Probit & $\begin{array}{c}\text { Probit } \\
\text { State FE }\end{array}$ & $\begin{array}{c}\text { Probit } \\
\text { DMA FE }\end{array}$ & OLS & $\begin{array}{c}\text { OLS } \\
\text { State FE }\end{array}$ & $\begin{array}{c}\text { OLS } \\
\text { DMA FE }\end{array}$ \\
\hline $\begin{array}{l}\text { NRT } \\
\text { advertising }\end{array}$ & $\begin{array}{r}0.0014 \\
(1.04)\end{array}$ & $\begin{array}{r}-0.0006 \\
(-0.48)\end{array}$ & $\begin{array}{r}-0.0005 \\
(-0.41)\end{array}$ & $\begin{array}{r}0.0159 \\
(2.06)\end{array}$ & $\begin{array}{r}0.0162 \\
(2.84)\end{array}$ & $\begin{array}{r}0.0172 \\
(2.93) \\
\end{array}$ \\
\hline $\begin{array}{l}\text { State price } \\
\text { cigarettes }\end{array}$ & $\begin{array}{r}-0.0009 \\
(-2.93)\end{array}$ & $\begin{array}{r}-0.0020 \\
(-4.85)\end{array}$ & $\begin{array}{r}-0.0007 \\
(-1.72)\end{array}$ & $\begin{array}{r}-0.0031 \\
(-2.13)\end{array}$ & $\begin{array}{r}-0.0041 \\
(-1.07)\end{array}$ & $\begin{array}{l}0.0000 \\
(-0.02)\end{array}$ \\
\hline $\begin{array}{l}\text { Student } \\
\text { income }\end{array}$ & $\begin{array}{l}0.0019 \\
(22.59)\end{array}$ & $\begin{array}{l}0.0018 \\
(24.46)\end{array}$ & $\begin{array}{l}0.0018 \\
(24.84)\end{array}$ & $\begin{array}{l}0.0066 \\
(22.75)\end{array}$ & $\begin{array}{l}0.0064 \\
(23.52)\end{array}$ & $\begin{array}{l}0.0064 \\
(23.43)\end{array}$ \\
\hline Male & $\begin{array}{r}-0.0182 \\
(-3.38)\end{array}$ & $\begin{array}{r}-0.0184 \\
(-3.39)\end{array}$ & $\begin{array}{r}-0.0187 \\
(-3.44)\end{array}$ & $\begin{array}{r}0.0992 \\
(5.25)\end{array}$ & $\begin{array}{r}0.1025 \\
(5.49)\end{array}$ & $\begin{array}{r}0.1020 \\
(5.47)\end{array}$ \\
\hline $\begin{array}{l}\text { African } \\
\text { American }\end{array}$ & $\begin{array}{l}-0.1527 \\
(-11.58)\end{array}$ & $\begin{array}{l}-0.1589 \\
(-13.48)\end{array}$ & $\begin{array}{l}-0.1593 \\
(-13.31)\end{array}$ & $\begin{array}{l}-0.6674 \\
(-12.88)\end{array}$ & $\begin{array}{l}-0.7014 \\
(-15.02)\end{array}$ & $\begin{array}{l}-0.7144 \\
(-14.39) \\
\end{array}$ \\
\hline Hispanic & $\begin{array}{r}-0.0224 \\
(-2.16) \\
\end{array}$ & $\begin{array}{r}-0.0150 \\
(-1.69) \\
\end{array}$ & $\begin{array}{r}-0.0099 \\
(-1.12) \\
\end{array}$ & $\begin{array}{r}-0.5017 \\
(-9.57) \\
\end{array}$ & $\begin{array}{l}-0.4500 \\
(-10.71) \\
\end{array}$ & $\begin{array}{l}-0.4340 \\
(-10.18) \\
\end{array}$ \\
\hline White & $\begin{array}{r}0.0810 \\
(7.77)\end{array}$ & $\begin{array}{r}0.0723 \\
(8.30)\end{array}$ & $\begin{array}{r}0.0687 \\
(7.90)\end{array}$ & $\begin{array}{r}0.1172 \\
(3.09)\end{array}$ & $\begin{array}{r}0.0767 \\
(2.12)\end{array}$ & $\begin{array}{r}0.0623 \\
(1.64)\end{array}$ \\
\hline Grade 10 & $\begin{array}{r}0.0698 \\
(6.30)\end{array}$ & $\begin{array}{r}0.0651 \\
(5.78)\end{array}$ & $\begin{array}{r}0.0652 \\
(5.71)\end{array}$ & $\begin{array}{r}0.2710 \\
(7.36)\end{array}$ & $\begin{array}{r}0.2713 \\
(9.44)\end{array}$ & $\begin{array}{r}0.2667 \\
(8.04)\end{array}$ \\
\hline Grade 12 & $\begin{array}{r}0.0828 \\
(8.65) \\
\end{array}$ & $\begin{array}{r}0.0793 \\
(9.02) \\
\end{array}$ & $\begin{array}{r}0.0784 \\
(8.39) \\
\end{array}$ & $\begin{array}{l}0.4038 \\
(11.12)\end{array}$ & $\begin{array}{l}0.4213 \\
(12.14) \\
\end{array}$ & $\begin{array}{l}0.4280 \\
(12.27) \\
\end{array}$ \\
\hline $\begin{array}{l}\text { Lives with } \\
\text { both parents }\end{array}$ & $\begin{array}{l}-0.0610 \\
(-14.50)\end{array}$ & $\begin{array}{l}-0.0609 \\
(-15.03)\end{array}$ & $\begin{array}{l}-0.0610 \\
(-14.79)\end{array}$ & $\begin{array}{l}-0.2779 \\
(-12.86)\end{array}$ & $\begin{array}{l}-0.2784 \\
(-13.03)\end{array}$ & $\begin{array}{l}-0.2785 \\
(-13.01)\end{array}$ \\
\hline $\begin{array}{l}\text { Parental } \\
\text { education }\end{array}$ & $\begin{array}{r}-0.0066 \\
(-4.80)\end{array}$ & $\begin{array}{r}-0.0063 \\
(-5.04)\end{array}$ & $\begin{array}{r}-0.0064 \\
(-4.94)\end{array}$ & $\begin{array}{l}-0.0777 \\
(-14.30)\end{array}$ & $\begin{array}{l}-0.0736 \\
(-13.56)\end{array}$ & $\begin{array}{l}-0.0732 \\
(-12.91)\end{array}$ \\
\hline March & $\begin{array}{r}0.0238 \\
(1.79) \\
\end{array}$ & $\begin{array}{r}0.0213 \\
(1.66) \\
\end{array}$ & $\begin{array}{r}0.0242 \\
(1.96) \\
\end{array}$ & $\begin{array}{r}0.1368 \\
(1.95) \\
\end{array}$ & $\begin{array}{r}0.0966 \\
(1.30)\end{array}$ & $\begin{array}{r}0.1148 \\
(1.68) \\
\end{array}$ \\
\hline April & $\begin{array}{r}0.0220 \\
(1.64) \\
\end{array}$ & $\begin{array}{r}0.0260 \\
(2.22) \\
\end{array}$ & $\begin{array}{r}0.0282 \\
(2.49) \\
\end{array}$ & $\begin{array}{r}0.1772 \\
(2.91) \\
\end{array}$ & $\begin{array}{r}0.1219 \\
(1.69) \\
\end{array}$ & $\begin{array}{r}0.1362 \\
(2.10) \\
\end{array}$ \\
\hline May & $\begin{array}{r}0.0011 \\
(0.08) \\
\end{array}$ & $\begin{array}{r}0.0138 \\
(1.18) \\
\end{array}$ & $\begin{array}{r}0.0181 \\
(1.58) \\
\end{array}$ & $\begin{array}{r}0.0896 \\
(1.50) \\
\end{array}$ & $\begin{array}{r}0.0539 \\
(0.78) \\
\end{array}$ & $\begin{array}{r}0.0784 \\
(1.23) \\
\end{array}$ \\
\hline June & $\begin{array}{r}-0.0417 \\
(-1.83)\end{array}$ & $\begin{array}{r}-0.0164 \\
(-1.30)\end{array}$ & $\begin{array}{r}-0.0057 \\
(-0.36)\end{array}$ & $\begin{array}{r}-0.2999 \\
(-2.22)\end{array}$ & $\begin{array}{r}-0.2339 \\
(-2.59)\end{array}$ & $\begin{array}{r}-0.2267 \\
(-3.14)\end{array}$ \\
\hline Constant & & & & $\begin{array}{r}1.7025 \\
(8.52) \\
\end{array}$ & $\begin{array}{r}1.6346 \\
(2.96)\end{array}$ & $\begin{array}{r}1.2844 \\
(4.13) \\
\end{array}$ \\
\hline R-Square & 0.0576 & 0.0627 & 0.0637 & 0.0971 & 0.1062 & 0.1083 \\
\hline Observations & 93,778 & 93,778 & 93,778 & 24,686 & 24,686 & 24,686 \\
\hline
\end{tabular}

${ }^{1}$ Not shown are dichotomous year variables in all models; also not shown are dichotomous state and DMA variables in the second and third models, respectively. Probit results are marginal effects; $z-$ and t-values reported in parentheses. The standard errors are clustered at the DMA level.

${ }^{2}$ Probit models report pseudo R-Square; OLS models report adjusted R-Square. 
Table 4

NRT Advertising Coefficients by Demographic Group limited to $1994-1997^{1}$

\begin{tabular}{|c|c|c|c|c|c|c|}
\hline \multirow{3}{*}{$\begin{array}{l}\text { Demographic } \\
\text { Group }\end{array}$} & \multicolumn{3}{|c|}{ Participation } & \multicolumn{3}{|c|}{ (LN) Use } \\
\hline & 1 & 2 & 3 & 1 & 2 & 3 \\
\hline & Probit & $\begin{array}{c}\text { Probit } \\
\text { State FE }\end{array}$ & $\begin{array}{c}\text { Probit } \\
\text { DMA FE }\end{array}$ & OLS & $\begin{array}{c}\text { OLS } \\
\text { State FE }\end{array}$ & $\begin{array}{c}\text { OLS } \\
\text { DMA FE }\end{array}$ \\
\hline $8^{\text {th }}$ grade & $\begin{array}{r}0.0014 \\
(0.70)\end{array}$ & $\begin{array}{r}0.0017 \\
(0.93)\end{array}$ & $\begin{array}{r}0.0014 \\
(0.60)\end{array}$ & $\begin{array}{r}0.0073 \\
(0.55)\end{array}$ & $\begin{array}{r}0.0166 \\
(1.23)\end{array}$ & $\begin{array}{r}0.0096 \\
(0.66)\end{array}$ \\
\hline $10^{\text {th }}$ grade & $\begin{array}{r}0.0020 \\
(0.71)\end{array}$ & $\begin{array}{r}0.0001 \\
(0.04)\end{array}$ & $\begin{array}{r}-0.0005 \\
(-0.16)\end{array}$ & $\begin{array}{r}-0.0013 \\
(-0.13)\end{array}$ & $\begin{array}{r}-0.0067 \\
(-0.66)\end{array}$ & $\begin{array}{r}-0.0050 \\
(-0.48)\end{array}$ \\
\hline $12^{\text {th }}$ grade & $\begin{array}{r}0.0019 \\
(0.47)\end{array}$ & $\begin{array}{r}0.0000 \\
(0.01)\end{array}$ & $\begin{array}{r}0.0004 \\
(0.10)\end{array}$ & $\begin{array}{r}0.0429 \\
(3.68)\end{array}$ & $\begin{array}{r}0.0416 \\
(4.69)\end{array}$ & $\begin{array}{r}0.0401 \\
(3.96)\end{array}$ \\
\hline Male & $\begin{array}{r}0.0014 \\
(0.84)\end{array}$ & $\begin{array}{r}-0.0006 \\
(-0.39)\end{array}$ & $\begin{array}{r}-0.0001 \\
(-0.07)\end{array}$ & $\begin{array}{r}0.0163 \\
(1.65)\end{array}$ & $\begin{array}{r}0.0166 \\
(2.32)\end{array}$ & $\begin{array}{r}0.0175 \\
(2.32) \\
\end{array}$ \\
\hline Fem & $\begin{array}{r}0.0012 \\
(0.76)\end{array}$ & $\begin{array}{r}-0.0007 \\
(-0.47)\end{array}$ & $\begin{array}{r}-0.0012 \\
(-0.79)\end{array}$ & $\begin{array}{r}0.0160 \\
(2.05)\end{array}$ & $\begin{array}{r}0.0165 \\
(2.76)\end{array}$ & $\begin{array}{r}0.0177 \\
(2.87)\end{array}$ \\
\hline $\begin{array}{l}\text { African } \\
\text { American }\end{array}$ & $\begin{array}{r}0.0015 \\
(0.84)\end{array}$ & $\begin{array}{r}0.0015 \\
(0.79)\end{array}$ & $\begin{array}{r}0.0022 \\
(1.20)\end{array}$ & $\begin{array}{r}0.0217 \\
(1.20)\end{array}$ & $\begin{array}{r}0.0255 \\
(1.23)\end{array}$ & $\begin{array}{r}0.0221 \\
(1.16)\end{array}$ \\
\hline Hispanic & $\begin{array}{r}-0.0003 \\
(-0.11) \\
\end{array}$ & $\begin{array}{r}-0.0036 \\
(-1.58) \\
\end{array}$ & $\begin{array}{r}-0.0042 \\
(-2.00) \\
\end{array}$ & $\begin{array}{r}0.0353 \\
(2.47) \\
\end{array}$ & $\begin{array}{r}0.0204 \\
(1.34) \\
\end{array}$ & $\begin{array}{r}0.0156 \\
(1.01) \\
\end{array}$ \\
\hline White & $\begin{array}{r}0.0019 \\
(1.04) \\
\end{array}$ & $\begin{array}{r}-0.0001 \\
(-0.05)\end{array}$ & $\begin{array}{r}0.0003 \\
(0.19) \\
\end{array}$ & $\begin{array}{r}0.0095 \\
(1.24) \\
\end{array}$ & $\begin{array}{r}0.0106 \\
(1.65) \\
\end{array}$ & $\begin{array}{r}0.0126 \\
(1.89)\end{array}$ \\
\hline Other & $\begin{array}{r}0.0002 \\
(0.07)\end{array}$ & $\begin{array}{r}-0.0029 \\
(-1.27)\end{array}$ & $\begin{array}{r}-0.0028 \\
(-1.27)\end{array}$ & $\begin{array}{r}0.0385 \\
(2.29)\end{array}$ & $\begin{array}{r}0.0385 \\
(2.33)\end{array}$ & $\begin{array}{r}0.0438 \\
(2.78)\end{array}$ \\
\hline
\end{tabular}

${ }^{1}$ Models include all variables included in table 3 . Probit results are marginal effects; $z$ - and t-values reported in parentheses. The standard errors are clustered at the DMA level. 